\title{
Community Fault Model (CFM) for Southern California
}

\author{
by Andreas Plesch, John H. Shaw, Christine Benson, William A. Bryant, Sara Carena, Michele \\ Cooke, James Dolan, Gary Fuis, Eldon Gath, Lisa Grant, Egill Hauksson, Thomas Jordan, Marc \\ Kamerling, Mark Legg, Scott Lindvall, Harold Magistrale, Craig Nicholson, Nathan Niemi, \\ Michael Oskin, Sue Perry, George Planansky, Thomas Rockwell, Peter Shearer, Christopher \\ Sorlien, M. Peter Süss, John Suppe, Jerry Treiman, and Robert Yeats.
}

\begin{abstract}
We present a new three-dimensional model of the major fault systems in southern California. The model describes the San Andreas fault and associated strikeslip fault systems in the eastern California shear zone and Peninsular Ranges, as well as active blind-thrust and reverse faults in the Los Angeles basin and Transverse Ranges. The model consists of triangulated surface representations (t-surfs) of more than 140 active faults that are defined based on surfaces traces, seismicity, seismic reflection profiles, wells, and geologic cross sections and models. The majority of earthquakes, and more than $95 \%$ of the regional seismic moment release, occur along faults represented in the model. This suggests that the model describes a comprehensive set of major earthquake sources in the region. The model serves the Southern California Earthquake Center (SCEC) as a unified resource for physics-based fault systems modeling, strong ground-motion prediction, and probabilistic seismic hazards assessment.
\end{abstract}

\section{Introduction}

Most current earthquake hazard assessments (e.g., Jackson et al., 1995; Frankel et al., 2002) are based on maps of surface fault traces (e.g., Jennings, 1994) and paleoseismic information obtained from trenching across faults. However, for nonplanar faults, faults that do not dip vertically or that are concealed beneath the Earth's surface (i.e., blind faults), more precise three-dimensional representations are needed to accurately define subsurface fault geometry. Precise fault system geometries better define earthquake source parameters, such as the fault surface area, and have been shown to have an important influence on slip rate estimates derived from geodetic constraints (e.g., Griffith and Cooke, 2005; Meade and Hager, 2005a) and on rupture dynamics (e.g., Poliakov et al., 2002; Ogelsby, 2005). Thus, scientists of the Southern California Earthquake Center (SCEC) have contributed to the development of a community-based three-dimensional fault model (CFM) for southern California to study active faulting and earthquake phenomena and to improve regional earthquake hazards assessments (Fig. 1). The CFM is currently being used to more accurately model crustal deformation based on observed geodetic displacements, to improve representations of earthquake sources and basin structure in order to predict strong ground motions, and to assess probabilistic seismic hazard (e.g., Aochi and Olson, 2004; Graves and Wald, 2004; Field et al., 2005; Griffith and Cooke, 2005; Meade and Hager, 2005a). This paper describes the CFM and how it was constructed and then eval- uates the completeness of the model based on comparisons with regional earthquake catalogs.

\section{Model Design and Construction}

The CFM is an object-oriented three-dimensional representation of more than 140 faults in southern California and adjacent offshore basins for which Quaternary activity has been established (or is deemed probable) and that are considered capable of producing moderate to large earthquakes. The CFM Working Group, which includes representatives from the U.S. Geological Survey (USGS), the California Geological Survey (CGS), and user groups in the SCEC, established the model inventory, building on the CGS fault database (Petersen et al., 1996, 1999; Cao et al., 2003). The model contains a wide variety of fault types and geometries, including vertical or steeply dipping strike-slip faults, dipping reverse faults, and low-angle blind thrusts. The model is fully populated from 32.5 to $36^{\circ} \mathrm{N}$ and from 114.5 to $120.5^{\circ} \mathrm{W}$ but also includes large continuous faults that extend into central California and northern Mexico (Fig. 2).

Faults in the CFM are represented as triangulated surfaces (t-surfs), which consist of nodes or points ( $x, y$, and $z$ ) associated with one another in triangular elements. T-surfs are advantageous because they accurately define complex surface geometries and topologies. Node (point) spacing is allowed to vary as a function of fault shape or data resolution. 


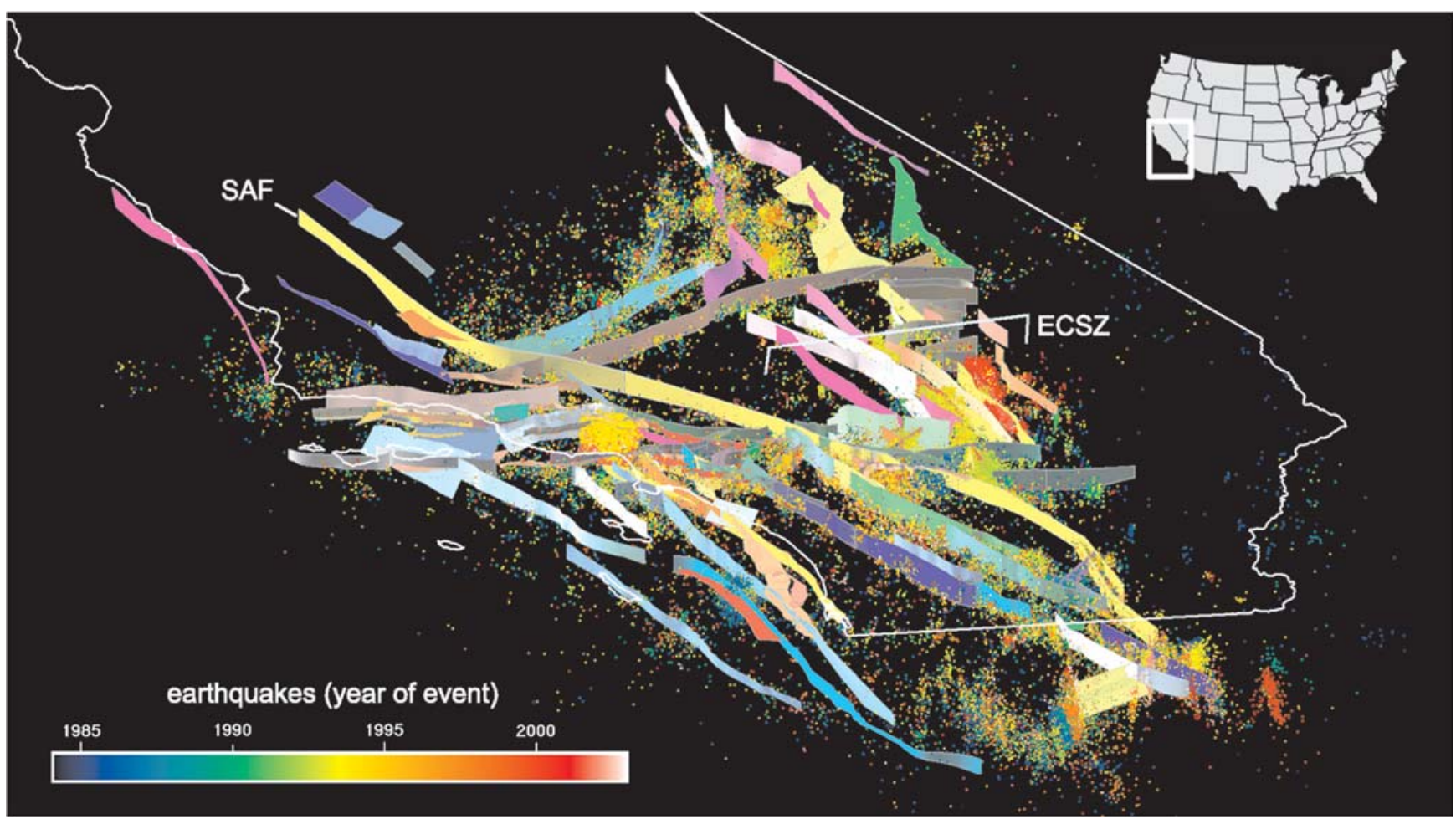

Figure 1. Perspective view of the CFM with seismicity $(M>1,1984-2003)$. The model is composed of triangulated surface representations of more than 140 active faults, including the San Andreas fault (SAF), the eastern California shear zone (ECSZ), and blind-thrust faults in the Los Angeles basin. Seismicity (Hauksson, 2000) is color coded by date. The color of the faults only serves to distinguish between faults and is not representative of activity.

Faults are bounded by topographic and bathymetric surfaces derived from USGS 3" digital elevation model data and a National Oceanic and Atmospheric Administration 30" grid (TerrainBase) and at depth by a regional base-of-seismicity surface (Nazareth and Hauksson, 2004). The modeled surfaces and horizons are provided in simple ASCII files in the Universal Transverse Mercator projection (zone 11, North American datum 1927, Clarke 1866 geoid).

Fault representations in the CFM are defined by many different types of constraints, including surface traces (e. g., Jennings, 1994), earthquake focal mechanisms and hypocentral distributions (Hauksson, 2000; Richards-Dinger and Shearer, 2000; Hauksson and Shearer, 2005; Shearer et al., 2005), well penetrations, seismic reflection profiles, and geologic cross sections (Fig. 3). These data were precisely registered in a geologic computer-aided design application (gOcad; Mallet, 1992), and portions of fault surfaces were interpolated from direct constraints. If available, digital data, with projection and datum information, were preferred over printed maps as the digital information could be reprojected with Geographic Information System (GIS) software without incurring significant location errors. Alternatively, maps were reprojected using a rubbersheeting process when coordinate ticks or geographic landmarks, such as road intersections or coastline features, could be precisely registered geographically. Cross sections were treated carefully with the understanding that some might be drawn by authors with the intent to illustrate an interpretation or tectonic model. It was our intent to respect the spatial positions of subsurface information. As a consequence, the vertical scale in some cross sections was found to be inconsistent with the horizontal scale as derived from distances between cross-section end points, wells, or fault traces. In situations where spatial inconsistencies within or between datasets were apparent, we maintained annotations and other metainformation about such data within gOcad in order to guide the subsequent fault modeling steps. This was achieved most effectively by importing, registering, reprojecting, and finally digitizing the original raster image. As an example, using this approach, we were able to digitize a fault trace in a cross section that had not been located precisely in the original work. We then shifted this information to the position of the map trace derived from a precisely registered geologic map, at each step recording the projection distances that might impact our estimate of spatial uncertainty in the final CFM representation.

Fault patches were interpolated from direct data constraints using discrete-smooth interpolation (Mallet, 1992) or linear relationships. The interpolated fault patches were then merged into continuous surfaces that define the complete faults. In the simplest cases, this involved extrapolating fault surfaces to depth from a surface trace at a fixed dip angle. In other cases, complex fault surfaces were constructed 


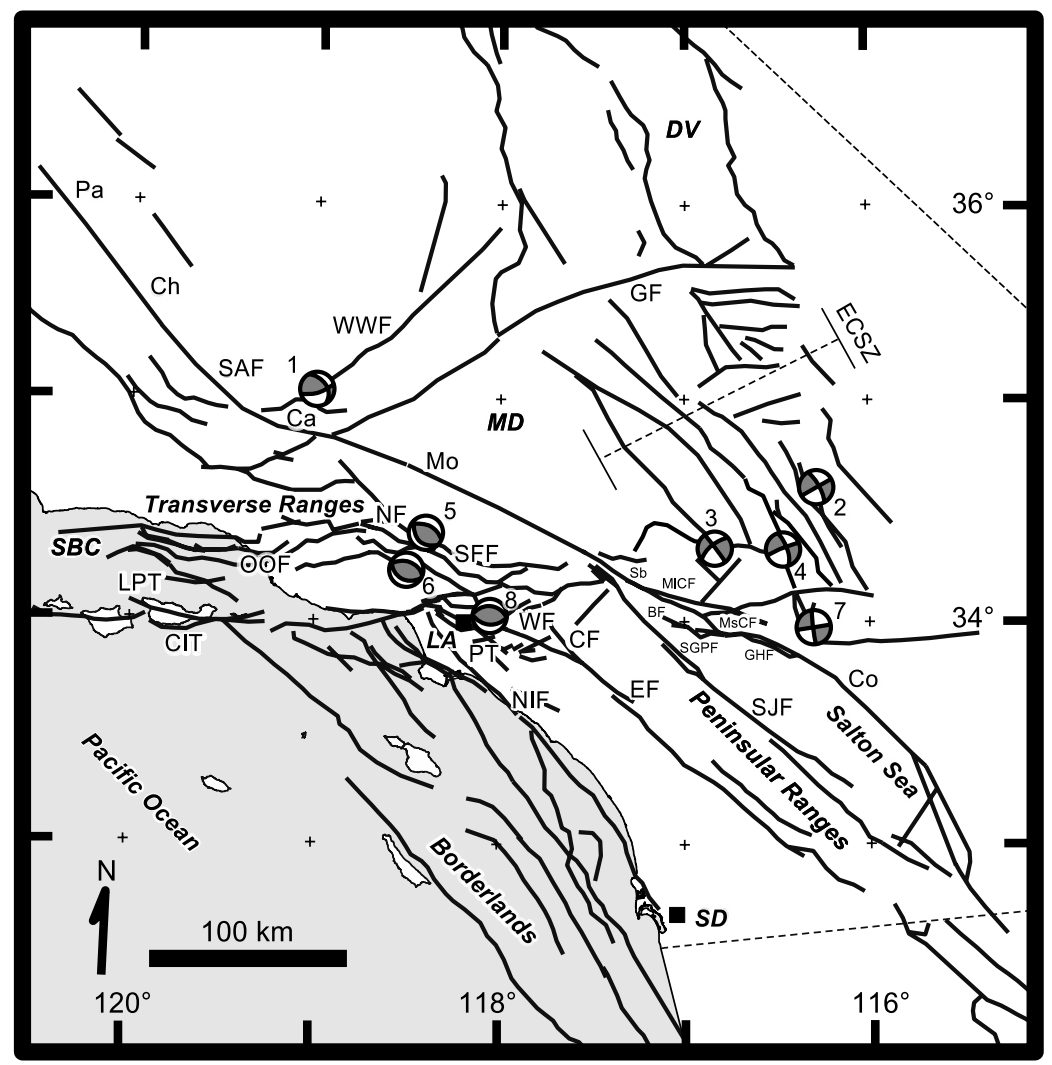

Figure 2. Map of southern California showing the geographic regions, faults, and focal mechanisms of earthquakes that are referred to in the text. Regions: Death Valley, DV; Mojave Desert, MD; Los Angeles, LA; Santa Barbara Channel, SBC; and San Diego, SD. Faults: The traces of all faults contained in the CFM are shown, but only the selection of faults that are mentioned in the text are labeled. Banning fault, BF; Channel Island thrust, CIT; Chino fault, CF; Eastern California Shear Zone, ECSZ; Elsinore fault, EF; Garlock fault, GF; Garnet Hill fault, GHF; Lower Pitas Point thrust, LPT; Mill Creek fault, MlCF; Mission Creek fault, MsCF; Northridge fault, NF; Newport Inglewood fault, NIF; offshore Oak Ridge fault, OOF; Puente Hills thrust, PT; San Andreas fault, SAF (sections: Parkfield, Pa; Cholame, Ch; Carrizo, Ca; Mojave, Mo; San Bernardino, Sb; and Coachella, Co), San Fernando fault, SFF; San Gorgonio Pass fault, SGPF; San Jacinto fault, SJF; Whittier fault, WF; and White Wolf fault, WWF. Focal mechanisms: 1952 Kern County, 1; 1999 Hector Mine, 2; 1992 Big Bear, 3 ; 1992 Landers, 4; 1971 San Fernando, 5; 1994 Northridge, 6; 1992 Joshua Tree, 7; and 1987 Whittier Narrows, 8.

from seismic reflection images, numerous well penetrations, and relocated earthquake clusters. The CFM database contains both interpolated fault patches and extrapolated complete fault surfaces as separate objects (Fig. 3) so that users can distinguish between well-constrained and more poorly constrained portions of fault surfaces.

The CFM database provides alternative representations for many of the faults. These alternative representations for a given fault may involve different levels of detail in the fault surfaces, different methods of interpolating or extrapolating fault surfaces between and within data constraints, or genuine differences among contributing scientists about the geometry and position of the fault. Alternative fault representations also arise based on the manner in which dipping faults intersect at depth (Fig. 4). One of two faults may terminate into the other, or two faults may mutually crosscut at depth, with one fault being offset by the other. Cases of fault interactions at depth are most common in areas where high-angle strike-slip faults and low-angle thrust faults are both present. Barring direct data constraints, several subsurface fault configurations may be reasonable (e.g., Rivero et al., 2000). The CFM attempts to represent those that are plausible. Each CFM version comprises a set of preferred fault representations selected from these alternatives. These preferred fault representations are designated by a quality factor that is assigned to each alternative fault representation by the CFM Working Group. The quality factor ranges from 1 to 5 and reflects the scientists' assessment of the geometric accuracy of the fault representation. A ranking of 1 describes a fault that is illuminated by a cluster of earthquakes, is imaged by seismic reflection surveys, and/or is penetrated by wells. A ranking of 3 generally indicates the fault is defined by a geologically mapped surface trace with dip data. A ranking of 5 indicates that the fault geometry is completely model driven, without direct subsurface or surface constraints. Each fault representation was evaluated by members of the Work- 


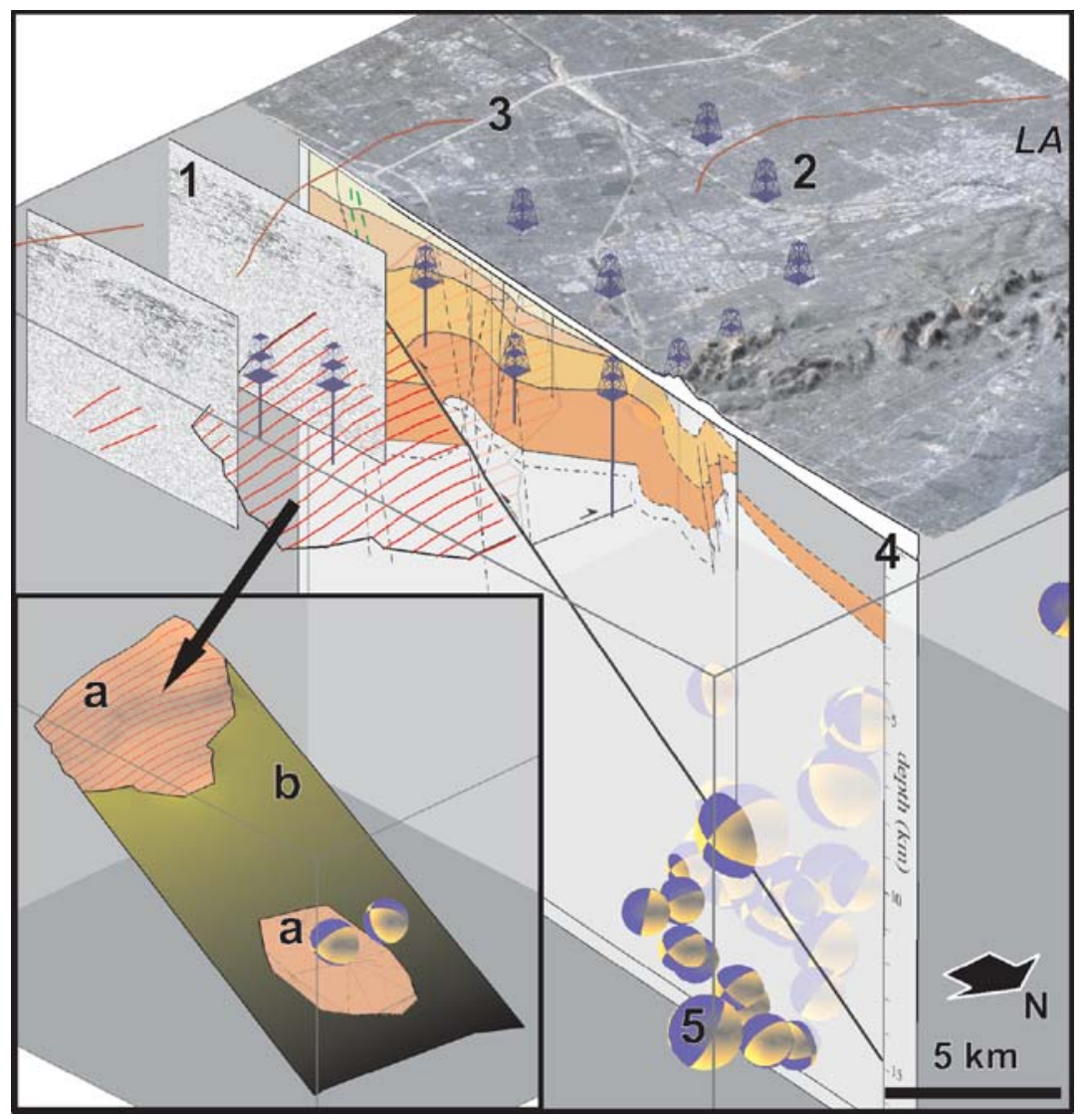

Figure 3. Fault surfaces in the CFM were constructed by first registering seismic (1) reflection profiles, (2) wells, (3) surface fault traces, (4) geologic cross sections, and (5) focal mechanisms in a geologic computer-aided design application (gOcad; Mallet, 1992). Inset: Fault patches were interpolated (a) directly from these constraints and extrapolated (b) to form complete surfaces.

ing Group. The rounded mean value is provided in the CFM database. In cases where alternative fault representations exist, the quality factor was the criterion used to define the preferred representation.

The Santa Monica fault system in the northern Los Angeles basin serves to illustrate how various geologic and geophysical data constraints were precisely registered and used to construct a CFM fault representation (Fig. 5). The Santa Monica fault system consists of a blind-thrust ramp that underlies the Santa Monica Mountains anticlinorium (Davis et al., 1989). This thrust ramp interacts near its southern margin with a series of steeply dipping left-lateral reverse faults comprising the Transverse Ranges Southern Boundary (TRSB) fault system (Dolan et al., 2000). The Santa Monica fault, as part of the TRSB system, can be resolved into two branches. One branch of the Santa Monica fault, the North Strand (Dolan et al., 2000), exhibits left-lateral slip whereas the second branch, the South Strand of Dolan et al. (2000), exhibits dominant reverse displacement. Portions of both fault strands are defined by a series of published geologic cross sections (Wright, 1991; Dolan and Pratt, 1997; Davis and Namson, 1998; Dolan et al., 2000; Tsutsumi et al., 2001; Yeats, 2001) that incorporate constraints from wells and high-resolution seismic reflection profiles. Moreover, the trace of the North Strand fault is defined by a series of young fault scarps (Dolan et al., 2000).

For the purpose of CFM, we sought to develop fault representations that accurately reflect these surface and subsurface constraints but also consider alternative ways in which the fault strands may interact and project to depth beyond our data constraints. Thus, we evaluate three alternative representations: the first where the two faults interpenetrate; the second, where the South Strand truncates into the footwall of the North Strand; and the third, where the North Strand terminates into the South Strand at depth. Construction of the third alternative, which was deemed the preferred solution by the CFM Working Group, is further described here.

The South Strand of the Santa Monica fault was defined by a roughly planar east-west striking surface with its upper tip line at a depth of 600 to $1000 \mathrm{~m}$, which is consistent with the cross-section well data along its entire length (Fig. 5). The fault was extended to depth at a dip of about $36^{\circ}$ in accordance with the geometry reflected in the cross sections by Davis and Namson (1998) and Tsutsumi et al. (2001). The projected fault surface was further constrained to follow the 

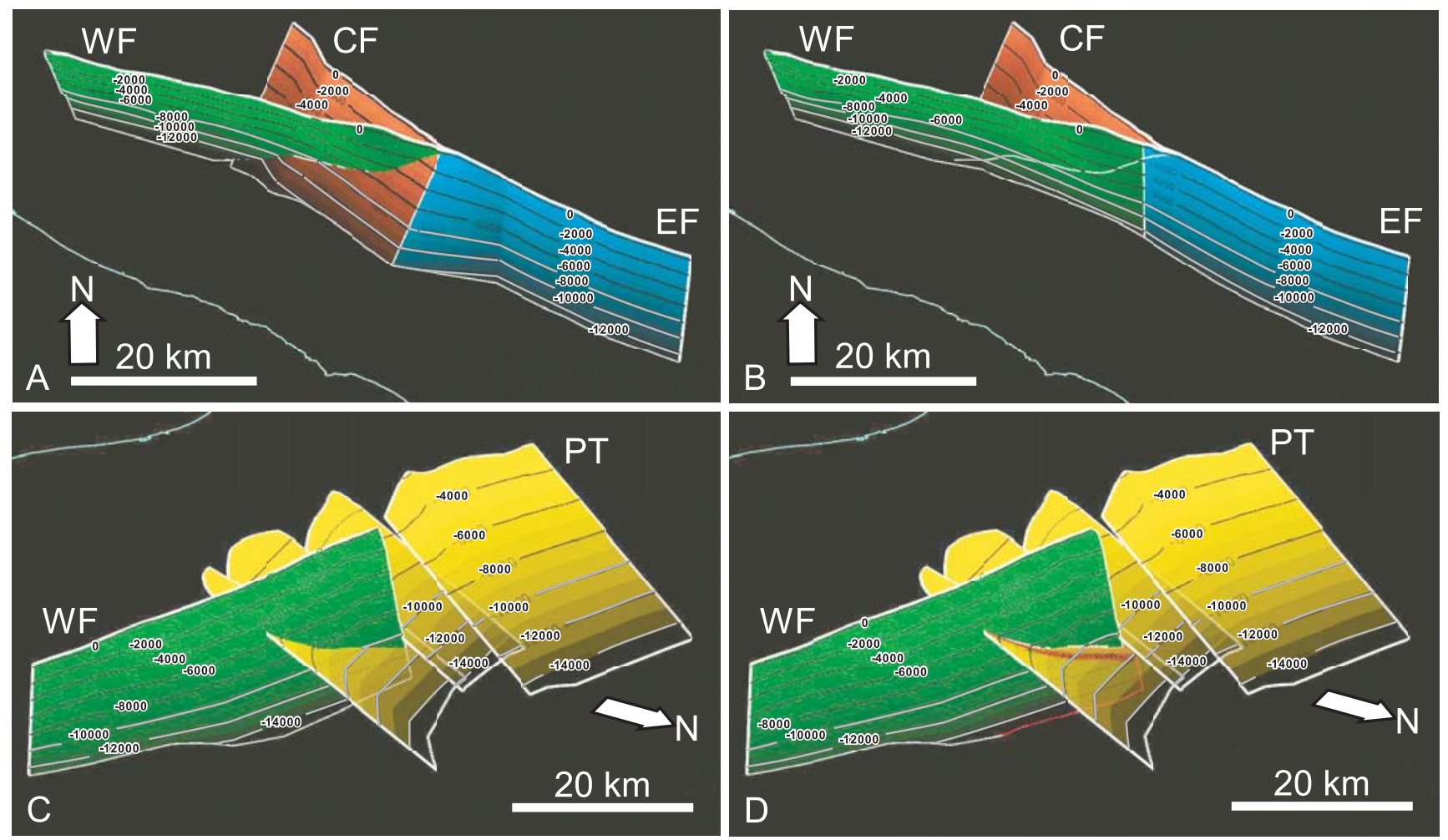

Figure 4. (a) and (b) Perspective view of alternative representations of the Whittier, WF; Chino, CF; and Elsinore, EF, faults. The depth contour line interval is $2000 \mathrm{~m}$. In (a), the Whittier fault terminates into the Chino fault at depth, whereas in (b) the Chino fault terminates into the Whittier fault. Note that representation (b), deemed the preferred alternative (see text for preference decision), yields a smoother connection between the Whittier and Elsinore faults as well as between the Chino and Elsinore faults that is apparent in the linearity of the contour lines. (c) and (d) Perspective view of the Whittier and Puente Hills fault alternative representations. In (c), the Whittier and Puente Hills (PT) faults intersect but do not displace each other, whereas in (d)the Whittier fault is displaced by slip (red lines across fault gap) on the Puente Hills fault (Shaw et al., 2002). The preferred alternative (d) respects proposed fault kinematics. The CFM contains similar alternative representations for many faults, reflecting uncertainties regarding the manner in which dipping faults intersect at depth.

strike of the overlying Santa Monica Mountains anticlinorium. As topography and the anticlinorial axis retreats to the north in the eastern half of the Santa Monica Mountains (east of cross section WH in Fig. 5), the fault surface was adjusted to parallel this change. The resulting projection of the South Strand of the Santa Monica fault yields a representation that is roughly planar at depth but increasingly detailed towards the surface. The North Strand of the fault was defined by cross sections and a published contour map and extended to depth where it was truncated by the underlying South Strand fault. The resulting pair of fault representations accurately complies with the data and model constraints, and thus we consider them a viable set of fault representations for the model.

\section{Model Database}

Fault representations and supporting information, including unique fault names and numbers, fault types, geologic slip rates, quality factors, and uncertainty estimates, are stored in a relational database (postgresql) that can be ac- cessed by a web interface (UMN, 2007). The interface allows users to download complete model versions or to construct their own fault models using geographic and attribute-based search criteria. The database also includes a detailed list of references that were used to constrain the various fault representations included in the CFM. The database is updated as new alternative fault representations are added and evaluated, but individual released CFM versions remain fixed. This paper describes release 3.0 of the CFM, as previous versions were developed principally for evaluation.

\section{Model Description}

The CFM describes a complex system of faults that define the North American-Pacific Plate boundary in southern California; it includes the offshore Borderlands, the Transverse and Peninsular Ranges, and the eastern California shear zone. The major plate boundary structure, the San Andreas fault (SAF), is composed of six sections (Parkfield, Cholame, Carrizo, Mojave, San Bernardino, and Coachella) that extend from Parkfield through the Big Bend to the Salt- 

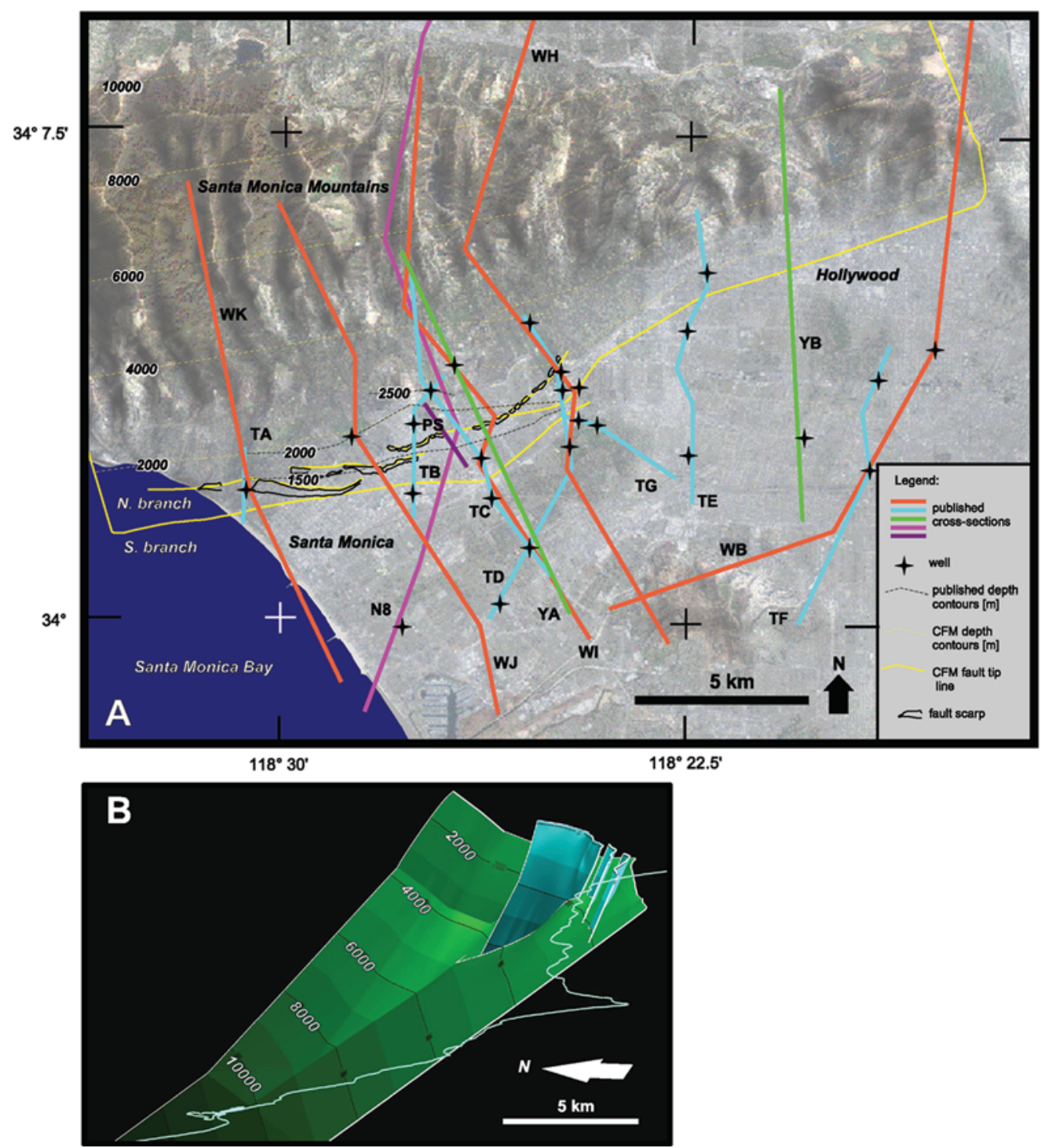

Figure 5. (a) Summary map of the data constraints used in constructing the CFM representation of the Santa Monica fault. The position of four sets of geologic cross sections; wells along cross sections; a seismic reflection profile, PS, dark purple (Dolan and Pratt, 1997); associated fault scarps (Dolan et al., 2000); and published depth contours (Tsutsumi et al., 2001) are shown. The outline and depth contours (2000-m interval) of the resulting CFM representation of the Santa Monica fault are also shown. The geologic cross sections are WB, WH, WI, WJ, and WK (orange; Wright, 1991); TA, TB, TC, TD, TE, TF, and TG (blue; Tsutsumi et al., 2001); YA and YB (green; Yeats, 2001); and N8 (light purple; Davis and Namson, 1998). All shown wells are identified in the literature cited for the cross sections. (b) Perspective view, looking east, of one CFM representation of the Santa Monica fault. The depth contour line interval is $2000 \mathrm{~m}$. In this alternative the North Strand (blue) merges into the South Strand (green).

on Sea. The CFM database contains a simple representation of the San Andreas fault, based on vertical projection from the surface traces. It also contains more complex representations of the fault for regions where bends or jogs occur and where it interacts with other faults. The highest degree of fault complexity occurs in the San Bernardino sections of the fault (Fig. 6), where the Banning, San Gorgonio Pass, Garnet Hill, Mill Creek, and Mission Creek faults all connect the west-northwest-striking Mojave section to the northweststriking Coachella section of the SAF. The steeply dipping Banning fault occurs above a depth of about $5 \mathrm{~km}$ in the hanging wall of the moderately north-dipping Garnet Hill and San Gorgonio Pass faults. The Garnet Hill fault itself gradually steepens to the northwest and southeast to join the vertical Mojave and Coachella sections of the SAF. To the southwest of the SAF, the San Jacinto fault-210-km long and illuminated by high rates of background seismicity-passes within $10 \mathrm{~km}$ of the San Gorgonio Pass fault and extends to within $3 \mathrm{~km}$ of the SAF to the northwest. This complex fault arrangement associated with the Big Bend of the SAF likely contributes to the variability in earthquake magnitudes and recurrence intervals observed in the paleo- 
seismic record (Biasi et al., 2002; Weldon et al., 2004). The complex arrangement may also explain in part the apparent discrepancy between geologic and geodetic slip rates for this and adjacent segments of the SAF (Bennett et al., 1996; Meade and Hager, 2005b; Weldon et al., 2004).

In the Mojave Desert region, the model includes a set of 33 strike-slip faults comprising the southern eastern California shear zone (Fig. 6), with geometries defined by maps of surface fault traces and seismicity, including the 1992 Joshua Tree (M 6.1), 1992 Landers (M 7.3), 1992 Big Bear (M 6.4), and 1999 Hector Mine (M 7.1) earthquakes. As most of the fault systems are vertical or steeply dipping, the subsurface fault architecture is relatively straightforward. However, the along-strike patterns of fault segmentation can be complex, as reflected by the Landers earthquake, which ruptured across sections of the Johnson Valley, Kickapoo, Homestead Valley, Emerson, and Camp Rock faults (Hart et al., 1993; Rockwell et al., 2000).

The eastern California shear zone extends north from the Mojave desert into the Death Valley region, across the Garlock fault. In the Death Valley region, the CFM includes alternative fault representations derived from different tectonic models that emphasize extensional detachments or strike-slip faults (Machette et al., 2001; Park and Wernicke, 2003). Between the Death Valley region and the SAF, the White Wolf fault and associated faults are based on models of the 1952 Kern County ( $M 7.5)$ earthquake as well as more recent seismicity (Bawden et al., 1999; Bawden, 2001).

In contrast to the vertical strike-slip faults that dominate the Peninsular Ranges and eastern California shear zone, the Los Angeles basin contains a complex array of strike-slip, reverse, and blind-thrust faults that interact at depth. Major northwest-trending strike-slip faults of the Peninsular Ranges (Elsinore, Whittier, and Newport-Inglewood) extend into the northern basin, where they intersect with east-westtrending reverse and blind-thrust faults (Wright, 1991; Shaw et al., 2002; Yeats, 2004). Blind-thrust faulting in the northern Los Angeles basin was initially described by Davis et al. (1989) as being predominantly manifest on a single thrust ramp (Elysian Park thrust), which was thought to have ruptured in the 1987 Whittier Narrows (M 6.0) earthquake. Subsequent analyses of the seismicity, subsurface basin structure, and tectonic geomorphology demonstrated that this blind-thrust structure is not manifest in a single fault but rather occurs on a vertically stacked set of at least six blind-thrust faults (Fig. 7). They include the lower Elysian

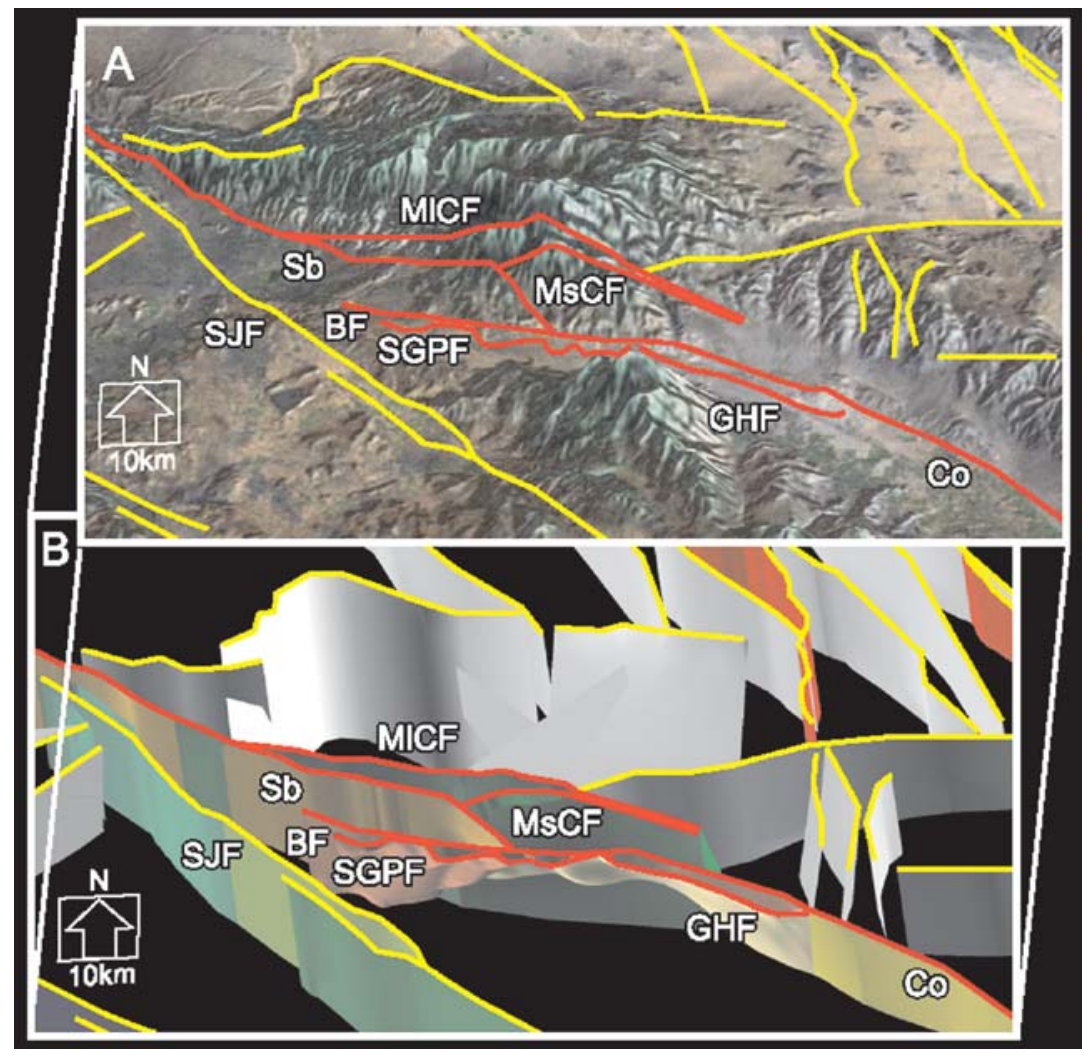

Figure 6. Perspective view looking north of the area surrounding the Big Bend in the San Andreas fault in two panels. (a) Shaded relief of topography (3:1 vertical exaggeration), with superimposed Landsat TM image and fault traces (yellow and red). Faults that are mentioned in the San Andreas fault discussion have red traces. (b) The CFM and superimposed fault traces repeated from (a). See the Figure 2 caption for fault labels and for numbered earthquakes. Only faults referred to in the text are labeled and colored. Other faults are gray. For scale, note the $10 \times 10-\mathrm{km}$ square surrounding the north arrow. 


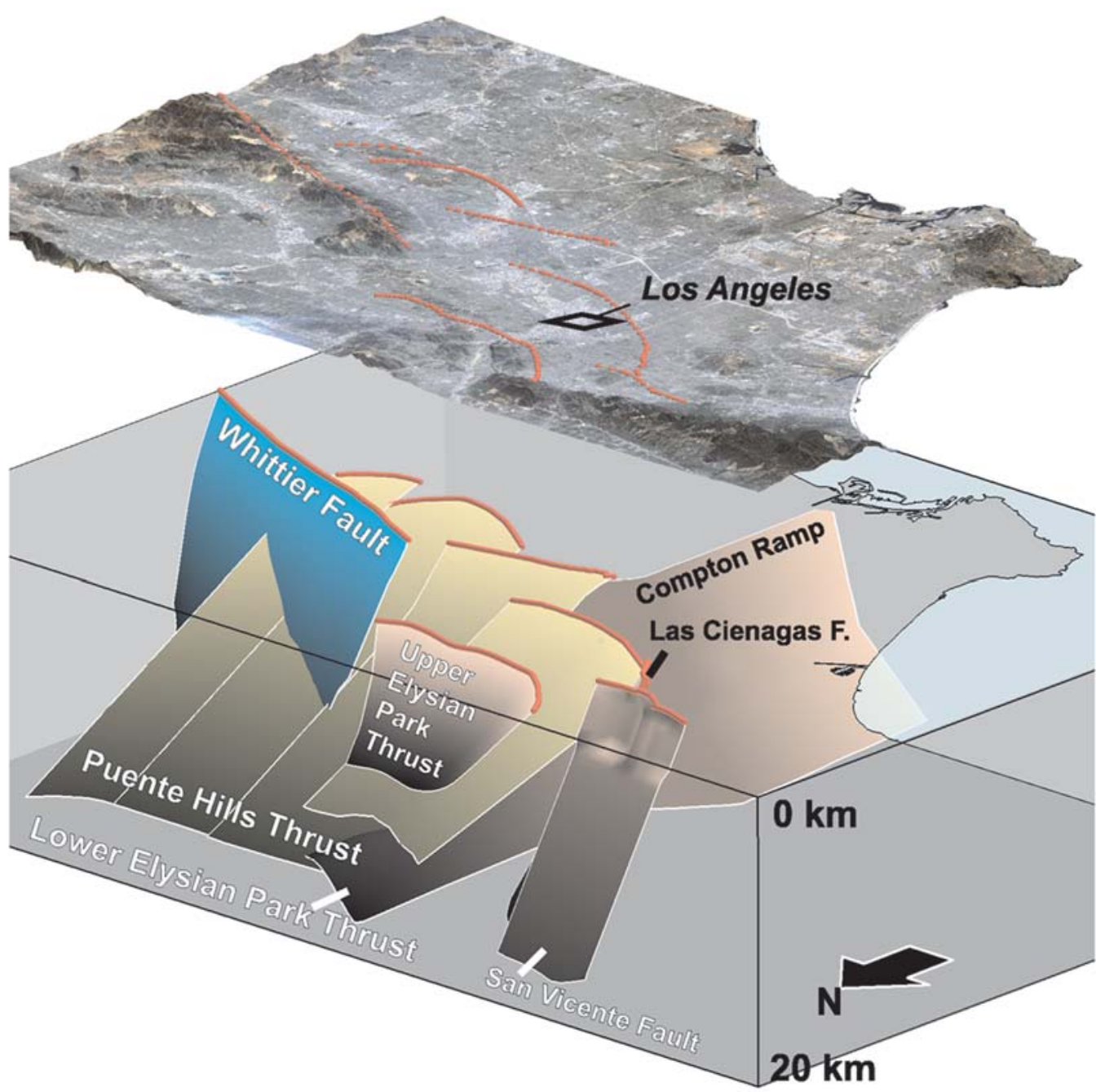

Figure 7. Perspective view of the CFM in the northern Los Angeles basin, showing an imbricate stack of six blind-thrust faults lying beneath the downtown region. Previous hazard compilations (Peterson et al., 1996, 1999; Frankel et al., 2002) considered only a single blindthrust earthquake source in the region.

Park, the three segments of Puente Hills, the San Vicente, the Las Cienagas, and the upper Elysian Park faults (Schneider et al., 1996; Shaw and Suppe, 1996; Shaw and Shearer, 1999; Oskin et al., 2000; Tsutsumi et al., 2001; Shaw et al., 2002). Nevertheless, ambiguity has remained in the seismic hazard assessments about whether these new studies have documented new seismic sources or simply have redefined and have renamed portions on the Elysian Park system. The process of building the CFM highlights the fact that these faults are defined by separate constraints and that they occur at different depths and positions. Thus, each fault represents a potentially independent earthquake source that is treated uniquely in the CFM and that is not linked to other faults. Furthermore, slip along these thrust faults, derived from offsets and folds of sedimentary strata, was used to model geometric and kinematic interactions with the major strike-slip faults, yielding several alternative fault configurations in the CFM.

The CFM in the Transverse Ranges and Santa Barbara Channel region also reflects a high degree of structural complexity, with major strike-slip, reverse, and blind-thrust faults. The San Fernando and Northridge faults are defined largely by aftershock clusters and modeled source rupture planes from the 1971 and $1994 M 6.7$ earthquakes (Heaton, 1982; Tsutsumi and Yeats, 1999; Fuis et al., 2003). Other faults in the region are defined by smaller earthquake clusters, surface traces, oil wells, seismic reflection data, and balanced geologic cross sections. Major alternative fault representations occur in the Santa Barbara Channel, reflecting uncertainties about whether active strike- and oblique-slip faults (such as the offshore Oak Ridge fault) extend continuously to the base of the seismogenic crust or merge into 
blind-thrust faults including the Channel Island and lower Pitas Point thrusts (Shaw and Suppe, 1994; Kamerling et al., 2003). By including these alternative representations, the CFM facilitates the consideration of these and other alternative source configurations in probabilistic seismic hazard assessments. The model is also intended to provide a basis for distinguishing between these alternative representations through further seismologic, geodetic, and geologic investigations.

\section{Faults and Seismicity}

To provide a sense of the completeness of the CFM, we examined the distribution of seismicity in southern California from 1981 to 2003 relative to the fault representations. Because seismicity was used to define many of the fault representations in the CFM, this comparison is not intended as an independent objective measure of the CFM geometric accuracy. However, it does provide a qualitative assessment of how well two-dimensional fault representations describe fault-zone deformation and demonstrates the completeness of the entire model. We measured the precise distance to hypocenters in three seismicity catalogs (Hauksson, 2000; Richards-Dinger and Shearer, 2000; Southern California Seismographic Network, 2004), starting from the closest point along the triangulated surface representations of the faults. Seismicity is centered on the fault surfaces and decays steadily with distance away from them, with the majority (>50\%) of events in all catalogs clustered within $4 \mathrm{~km}$ on either side of a fault surface. Part of this $\pm 4 \mathrm{~km}$ spread can be attributed to the uncertainty of hypocenter locations in the catalogs, which was found to be generally less than $\pm 2 \mathrm{~km}$ where provided. The remaining $\pm 2 \mathrm{~km}$ distribution in seismicity is likely explained by off-fault deformation related to splays and secondary faults that are not represented in the CFM. Moreover, we find that earthquakes within the $\pm 4 \mathrm{~km}$ zone around the faults released greater than $95 \%$ of the seismic moment in southern California. The seismic moment release for this time period is dominated by the 1992 Landers (M 7.3) and 1999 Hector Mine (M 7.1) earthquakes, which released $93 \%$ of the total moment in southern California and which are located on fault surfaces within the $\pm 2 \mathrm{~km}$ uncertainty of the fault positions. The close association of seismicity with the faults (see also Woessner et al., 2006) indicates that the CFM describes a comprehensive set of major earthquake sources in the region. Thus, the SCEC is currently using the CFM as the basis for its efforts in fault systems analysis, strong ground-motion prediction, and earthquake hazards assessment. By supporting such studies in southern California, we hope that the CFM and similar models developed elsewhere in the world will advance earthquake systems science, thereby offering important benefits to the public through improved earthquake hazard assessments.

\section{Acknowledgments}

We thank the Southern Californian Earthquake Center (SCEC) for financial and scientific support in this effort. The methods used in constructing the fault model were developed with support of NSF Grant Number 0087648. We also thank students at Harvard who have helped tremendously in developing the model and its supporting database, including P. Fiore, N. Williams, P. Lovely, K. Bergin, J. Doblecki, L. Nousek, A. Larson, and M. Zacchilli. We also offer thanks to D. Kilb and G. Kent at the Scripps Institution of Oceanography Visualization Center, which hosted a workshop to help build and evaluate the CFM.

\section{References}

Aochi, A., and K. B. Olsen (2004). On the effects of non-planar geometry for blind thrust faults on strong ground motion, Pageoph 161, 2139-2153.

Bawden, G. W. (2001). Source parameters for the 1952 Kern County earthquake, California: a joint inversion of leveling and triangulation observations, J. Geophys. Res. 106, 771-785.

Bawden, G. W., A. J. Michael, and L. H. Kellogg (1999). Birth of a fault: connecting the Kern County and Walker Pass, California, earthquakes, Geology 27, 601-604.

Bennett, R. A., W. R. Rodi, and E. Reilinger (1996). Global positioning system constraints on fault slip rates in Southern California and northern Baja, Mexico, J. Geophys. Res. 101, 21,943-21,960.

Biasi, G. P., R. J. Weldon, T. E. Fumal, and G. G. Seitz (2002). Paleoseismic event dating and the conditional probability of large earthquakes on the southern San Andreas Fault, California, Bull. Seismol. Soc. Am. 92, 2761-2781.

Cao, T., W. A. Bryant, B. Rowshandel, D. Branum, and C. J. Wills (2003). The revised 2002 California Probabilistic Seismic Hazard Maps June 2003, Calif. Div. Mines Geol., 12 pp.: available at http://www.consrv. ca.gov/cgs/rghm/psha/fault_parameters/pdf/2002_CA_Hazard_Maps. pdf (accessed throughout 2004).

Davis, T. L., and J. S. Namson (1998). Detection, characterization and seismic potential of blind thrusts in Southern California, final NEHRP report, 1:250000, 12 pp.: available at http://www.davisnamson.com (accessed 2003 and 2004).

Davis, T. L., J. Namson, and R. F. Yerkes (1989). A cross section of the Los Angeles area: seismically active fold and thrust belt, the 1987 Whittier Narrows earthquake, and earthquake hazard, J. Geophys. Res. 94, 9644-9664.

Dolan, J. F., and T. Pratt (1997). High-resolution seismic reflection profiling of the Santa Monica fault zone, West Los Angeles, California, Geophys. Res. Lett. 24, 2051-2054.

Dolan, J. F., K. Sieh, and T. K. Rockwell (2000). Late Quaternary activity and seismic potential of the Santa Monica fault system, Los Angeles, California, Geol. Soc. Am. Bull. 112, 1559-1581.

Field, E. H., H. A. Seligson, N. Gupta, V. Gupta, T. H. Jordan, and K. W. Campbell (2005). Loss estimates for a Puente Hills blind-thrust earthquake in Los Angeles, California, Earthq. Spectra 21, 329-338.

Frankel, A. D., M. D. Petersen, C. S. Mueller, K. M. Haller, R. L. Wheeler, E. V. Leyendecker, R. L. Wesson, S. C. Harmsen, C. H. Cramer, D. M. Perkins, and K. S. Rukstales (2002). Documentation for the 2002 Update of the National Seismic Hazard Maps, U.S. Geol. Surv. Open-File Rept. 02-420, 33 pp.

Fuis, G. S., R. W. Clayton, P. M. Davis, T. Ryberg, W. J. Lutter, D. A. Okaya, E. Hauksson, C. Prodehl, J. M. Murphy, M. L. Benthien, S. A. Baher, M. D. Kohler, K. Thygesen, G. Simila, and G. R. Keller (2003). Fault systems of the 1971 San Fernando and 1994 Northridge earthquakes, Southern California: relocated aftershocks and seismic images from LARSE II, Geology 31, 171-174.

Graves, R. W., and D. J. Wald (2004). Observed and simulated ground motions in the San Bernardino basin for the Hector Mine, California, earthquake, Bull. Seismol. Soc. Am. 94, 131-146. 
Griffith, W. A., and M. L. Cooke (2005). How sensitive are fault-slip rates in the Los Angeles basin to tectonic boundary conditions?, Bull. Seismol. Soc. Am. 95, 1263-1275.

Hart, E. W., W. A. Bryant, and J. A. Treiman (1993). Surface faulting associated with the June 1992 Landers earthquake, California, Calif. Geol. 46, 10-16.

Hauksson, E. (2000). Crustal structure and seismicity distribution adjacent to the Pacific and North America plate boundary in Southern California, J. Geophys. Res. 105, 13,875-13,903.

Hauksson, E., and P. Shearer (2005). Southern California hypocenter relocation with waveform cross-correlation, part 1: Results using the double-difference method, Bull. Seismol. Soc. Am. 95, 896-903.

Heaton, T. H. (1982). The 1971 San Fernando earthquake; a double event? Bull. Seismol. Soc. Am. 72, 2037-2062.

Jackson, D. D., K. Aki, C. A. Cornell, J. H. Dieterich, T. L. Henyey, M. Mahdyiar, D. Schwartz, and S. N. Ward (, and Working Group on California Earthquake Probabilities) (1995). Seismic hazards in Southern California: probable earthquakes, 1994 to 2024, Bull. Seismol. Soc. Am. 85, 379-439.

Jennings, C. W. (Compiler) (1994). Fault activity map of California and adjacent areas, California Department of Conservation, Division of Mines and Geology, Geologic Data Map No. 6, scale 1:750,000.

Kamerling, M. J., C. C. Sorlien, and C. Nicholson (2003). 3D development of an active oblique fault system, northern Santa Barbara Channel, California (abstract), Seism. Res. Lett. 74, 248.

Machette, M. N., M. L. Johnson and J. L. Slate (Editors) (2001). Quaternary and Late Pliocene geology of the Death Valley region: recent observations on tectonics, stratigraphy, and lake cycles (guidebook for the 2001 Pacific Cell-Friends of the Pleistocene fieldtrip), U.S. Geol. Surv. Open-File Rept. 01-0051, 246 pp.

Mallet, J. L. (1992). Three-dimensional modeling with geoscientific information systems in Series C: Mathematical and Physical Sciences 354, A. K. Turner, (Editor), NATO ASI Series, Kluwer, Dordrecht, 123141.

Meade, B. J., and B. H. Hager (2005a). Spatial localization of moment deficits in Southern California, J. Geophys. Res. 110, B04402, doi 10.1029/2004JB003331

Meade, B. J., and B. H. Hager (2005b). Block models of crustal motion in Southern California constrained by GPS measurements, J. Geophys. Res. 110, B03403, doi 10.1029/2004JB003209.

Nazareth, J. J., and E. Hauksson (2004). The seismogenic thickness of the Southern California crust, Bull. Seismol. Soc. Am. 94, 940-960.

Oglesby, D. D. (2005). The dynamics of strike-slip stepovers with linking dip-slip faults, Bull. Seismol. Soc. Am. 95, 1604-1622.

Oskin, M., K. Sieh, T. Rockwell, G. Miller, P. Guptill, M. Curtis, S. McArdle, and P. Elliot (2000). Active parasitic folds on the Elysian Park Anticline: implications for seismic hazard in central Los Angeles, California, Geol. Soc. Am. Bull. 112, 693-707.

Park, S. K., and B. Wernicke (2003). Electrical conductivity images of Quaternary faults and Tertiary detachments in the California Basin and Range, Tectonics 22, 1030, doi 10.1029/2001tc001324.

Petersen, M. D., W. A. Bryant, C. H. Cramer, T. Cao, M. S. Reichle, A. D. Frankel, J. J. Lienkaemper, P. A. McCrory, and D. P. Schwartz (1996). Probabilistic seismic-hazard assessment for the state of California, $\mathrm{Ca}$ lif. Div. Mines Geol. Open-File Rept. 96-08 or U.S. Geol. Surv. OpenFile Rept. 96-706, 33 pp.

Petersen, M. D., D. Beeby, W. Bryant, T. Cao, C. Cramer, J. Davis, M. Reichle, G. Savcedo, S. Tan, G. Taylor, T. Toppozada, J. Treiman, and C. Wills (Compilers) (1999). Seismic shaking hazard maps of California, Calif. Div. Mines Geol., Map Sheet 48, scale 1:2,534,400.

Poliakov, A. N. B, R. Dmowska, and J. R. Rice (2002). Dynamic shear rupture interactions with fault bends and off-axis secondary faulting, J. Geophys. Res. 107, 2295, doi 10.1029/2001JB000572.

Richards-Dinger, K. B., and P. M. Shearer (2000). Earthquake locations in Southern California obtained using source-specific station terms, J. Geophys. Res. 105, 10,939-10,960.
Rivero, C., J. H. Shaw, and K. J. Mueller (2000). Oceanside and Thirtymile Bank blind thrusts: implications for earthquake hazards in coastal Southern California, Geology 28, 891-894.

Rockwell, T., S. Lindvall, M. Herzberg, D. Murbach, T. Dawson, and G. Berger (2000). Paleoseismology of the Johnson Valley, Kickapoo, and Homestead Valley faults: clustering of earthquakes in the eastern California shear zone, Bull. Seismol. Soc. Am. 90, 1200-1236.

Schneider, C. L., C. Hummon, R. S. Yeats, and G. J. Huftile (1996). Structural evolution of the northern Los Angeles Basin, California, based on growth strata, Tectonics 15, 341-355.

Shaw, J. H., and P. M. Shearer (1999). An elusive blind-thrust fault beneath metropolitan Los Angeles, Science 283, 1516-1518.

Shaw, J. H., and J. Suppe (1994). Active faulting and growth folding in the eastern Santa Barbara Channel, California, Geol. Soc. Am. Bull. 106, 607-626.

Shaw, J. H., and J. Suppe (1996). Earthquake hazards of active blind-thrust faults under the central Los Angeles Basin, California, J. Geophys. Res. 101, 8623-8642.

Shaw, J. H., A. Plesch, J. F. Dolan, T. L. Pratt, and P. Fiore (2002). Puente Hills blind-thrust system, Los Angeles, California, Bull. Seismol. Soc. Am. 92, 2946-2960.

Shearer, P., E. Hauksson, and G. Lin (2005). Southern California hypocenter relocation with waveform cross correlation, part 2: Results using source-specific station terms and cluster analysis, Bull. Seismol. Soc. Am. 95, 904-915.

Southern California Seismographic Network (2004). Catalog: available at http://www.data.scec.org/ftp/catalogs/SCSN/ (last accessed fall 2004).

Tsutsumi, H., and R. S. Yeats (1999). Tectonic setting of the 1971 Sylmar and 1994 Northridge earthquakes in the San Fernando Valley, California, Bull. Seismol. Soc. Am. 89, 1232-1249.

Tsutsumi, H., R. S. Yeats, and G. J. Huftile (2001). Late Cenozoic tectonics of the northern Los Angeles fault system, California, Geol. Soc. Am. Bull. 113, 454-468.

University of Minnesota (UMN) (2007). UMN MapServer: available from UMN at http://mapserver.gis.umn.edu/.

Weldon, R., K. Scharer, T. Fumal, and G. Biasi (2004). Wrightwood and the earthquake cycle: what a long recurrence record tells us about how faults work, GSA Today 14, 4-10.

Woessner, J., E. Hauksson, A. Plesch, J. Shaw, and R. Wesson (2006). Associating southern California seismicity with late Quaternary faults: 2006 Annual Meeting, Seismological Society of America, Seism. Res. Lett. 77, 252-253.

Wright, T. L. (1991). Structural geology and tectonic evolution of the Los Angeles Basin, California, in Active Margin Basins, K. T. Biddle (Editor), Am. Assoc. Petrol. Geol. Memoir Vol. 52, 35-134.

Yeats, R. S. (2001). Cross sections of the northern Los Angeles basin, California, 11 sections: available at http://terra.geo.orst.edu/people/ faculty/yeatsr.htm (accessed 2002 and 2003).

Yeats, R. S. (2004). Tectonics of the San Gabriel basin and surroundings, Southern California, Geol. Soc. Am. Bull. 116, 1158-1182.

Department of Earth and Planetary Sciences

Harvard University

20 Oxford St.

Cambridge, Massachusetts 02138

(A.P., J.H.S., C.B., G.P.)

Southern California Earthquake Center (SCEC)

University of Southern California

3651 Trousdale Parkway, Suite 169

Los Angeles, California 90089-0742

(W.A.B., S.C., M.C., J.D., G.F., E.G., L.G., E.H., T.J., M.K., M.L., S.L., H.M., C.N., N.N., M.O., S.P., T.R.)

Manuscript received 16 June 2005 